\title{
The role of regional economic integrations for trade margins: A case of Croatia*
}

\author{
Katja Zajc Kejžar ${ }^{1}$, Črt Kostevc ${ }^{2}$, Vinko Zaninović ${ }^{3}$
}

\begin{abstract}
The goal of this investigation is to research the development of intensive and extensive trade margins on product-country level data for Croatia during the period 2000-2012. Hypothesis of our paper is that RTAs-induced trade liberalization will have heterogeneous effects on particular product groups with indirect implications on national welfare. Static and dynamic gravity trade models are used on panel data accounting for over $90 \%$ of total trade during the observed period. Estimations of the trade gravity model and trade margins showed that while SAA and CEFTA arrangements positively affected different measures of intensive and extensive trade margins, specially exports and imports of consumption products, effects on trade in intermediate and capital goods were relatively subdued. This suggests a tendency for market-seeking rather than efficiency-seeking behaviour of Croatia's trade sector. When comparing the results for two trade agreements using dynamic model, we find that SAA primarily affected trade in consumption goods while effects of CEFTA are more evenly dispersed across different product groups. Main conclusion of the paper is that Croatia's policy makers should try to keep the preferential status of Croatia within the CEFTA market in the medium term, focusing on the Croatian economy.
\end{abstract}

Key words: trade margins, gravity model, free trade agreements, Croatia

JEL classification: F10, F12, F15

\footnotetext{
* Received: 29-02-2016; accepted: 17-06-2016

1 Associate Professor, University of Ljubljana, Faculty of Economics, Kardeljeva ploščad 17, 1000 Ljubljana, Slovenia. Scientific affiliation: international economics. Phone: +386 15892 643. E-mail: katja.zajc@ef.uni-lj.si.Personalwebsite: http://www.ef.uni-lj.si/person/Katja-ZajcKejzar.

2 Associate Professor, University of Ljubljana, Faculty of Economics, Kardeljeva ploščad 17, 1000 Ljubljana, Slovenia. Scientific affiliation: international economics. Phone: +386 15892 643. E-mail: crt.kostevc@ef.uni-lj.si.Personal website: http://www.ef.uni-lj.si/person/CrtKostevc.

${ }^{3}$ MA, Teaching and Research Assistant, University of Rijeka, Faculty of Economics, Ivana Filipovića 4, 51000 Rijeka, Croatia. Scientific affiliation: international economics. Phone: +38551355162. E-mail:vinko.zaninovic@efri.hr.Personal website: https://www.efri.uniri.hr/personnel/asistent/ zaninovic-vinko (corresponding author).
} 


\section{Introduction}

Since Viner (1950)'s pioneering work on trade creation and diversion the existence and the nature of the trade effects of the regional trade agreements (RTAs) have received substantial attention in the empirical trade literature. The research interest intensified with the surge of new free trade agreements in the 1990s and gradual slowdown of the progress of liberalisation at the multilateral level. Trade creating/diverting effects of RTAs are predominately assessed within gravity model framework which has asserted itself as a standard tool in the analysis of bilateral trade flows since its introduction to international trade analysis by Tinbergen (1962). The gravity model is particularly well suited for estimating trade elasticities with respect to trade costs. Since free trade agreements are one of the most important factors in lowering the trade costs, opting for the gravity model seems an obvious choice for testing the trade effects of the agreements. Signing of an RTA means first and foremost the (usually gradual) removal of tariffs between signatories, so they can be considered as a factor of variable costs savings. It should also be noted that the new generation of RTAs (deep RTAs) goes beyond simply removing trade barriers, by including production sharing provisions, e.g. IPR protection, regulations and standards, bearing implications also for the reduction in fixed costs of exporting. By fixed costs we assume costs of engaging in exports and the costs of penetration on new foreign markets (for example, costs of market research, costs of establishing foreign distribution networks and marketing costs.).

What we aim to test in this paper is how discriminatory liberalisation based on free trade agreements affects trade along intensive and extensive margins and how these effects vary across product categories according to broad economic purpose (Broad Economic Classification, thereinafter BEC). The reason for using this classification is twofold. First, it is expected that elasticity of substitution, which is a critical parameter in the adjustment along different trade margins, differs systematically among these product categories. Following Frensch (2010) we argue that goods used in production are more complementary than consumer goods, in whichever industry they may have been produced ${ }^{4}$. Secondly, it allows us to isolate effects of trade liberalization on trade in intermediates and capital goods, which are presenting the fastest growing segment of international trade and are found to have import role for economic growth (Grossman and Helpman, 1991; Eaton and Kortum, 2001).

Presuming that RTAs are resulting in relatively stronger reduction in variable trade costs we expect in line with Chaney (2008) stronger extensive margin effects of liberalisation for intermediate and capital goods (goods characterized by lower

$\overline{4}$ Frensch (2010) refers to estimates in Broda and Weinstein (2006) suggesting a substitution elasticity of 6 for consumer goods, whereas Jones (2008) works with an elasticity of substitution among intermediate goods of 0.5 . 
substitutability) compared to consumer goods while intensive margin effects are expected to be stronger for consumer goods relative to intermediates and capital goods. Differentiating goods categories by use Frensch (2010), indeed, found robust evidence of stronger extensive import margin effects of unilateral institutional trade liberalization, which he argues to reflect fixed trade costs, for intermediate and capital goods compared to consumer goods.

In this paper we test aforementioned theoretic and empirical background for the case of Croatia. Since Croatia is a small open economy that through 2000s experienced significant increase of trade flows with regional economies (mainly countries that, together with Croatia, formed Yugoslavia up to 1990) and European Union member countries, we believe that testing of RTA effects in the case of Croatia will confirm existent empirical results in this research field, but also give some new insights; since Croatia is import oriented country, it will be interesting to test whether the trade liberalization effects of RTAs are different (and the size of difference) for export versus import trade margins. Moreover, comparison of SAA and CEFTA trade liberalization effects can give answers how membership in two different trade agreements (different by the economical size of constituent economies) affects trade flows. Furthermore, estimations of impact of RTAs on intermediate, consumption and capital goods are base point for indirect inference on trade liberalization-induced welfare changes.

We test the RTA effects on intensive and extensive trade margins of Croatian firms throughout the period 2000-2012. We proxy variable trade costs with two free trade agreements (with EU and with CEFTA countries) that Croatia signed during that period (trade parts of the Agreement entered into force in 2002 and 2007 respectively). By using an augmented gravity model on product level we estimate trade margins elasticities with respect to variable trade costs changes. We argue that mentioned agreements will have more impact on the variable than on the fixed trade costs. Our reasoning is the following: before aforementioned RTAs came into force, Croatia's foreign trade was already predominately oriented towards EU (around $61 \%$ of Croatia's exports and $56 \%$ of imports in 2001), future EU member states that formed original CEFTA $^{5}(13 \%$ of exports and $19 \%$ of imports in 2003) and the countries that would become CEFTA 2006 member countries in 2007 (16\% of exports and $4 \%$ of imports in 2006). Our line of reasoning is that the incumbent firms have already overcome fixed (sunk) costs of exporting (so the effect of potential lowering of the fixed costs due to RTA will have limited impact), while we argue that new foreign market entrants could face lower fixed costs more due to the networking effect (since they are exporters to "traditional markets") than from lowering of fixed costs induced by RTAs). Similar reasoning is valid for importers.

\footnotetext{
5 Original CEFTA agreement was signed in 1992, with Visegrád Group countries as the founding members. Slovenia, Bulgaria and Romania became members in 1996, 1997 and 1999 respectively. When we use CEFTA acronym later in text, we are always referring to CEFTA 2006.
} 
Also, a priori we expect that there will be difference between SAA and CEFTA impact of trade margins due to specifics of each of the agreements:

- SAA (Stabilisation and Association Agreement) is an Agreement that goes beyond establishing free trade area between signatories and includes harmonisation of political and economical objectives as well as regional cooperation, although in the short term focus was on promoting the bilateral trade (non-trade parts of the agreement where fully implemented only from 2005).

- CEFTA (Central European Free Trade Agreement) is technically also covering other areas beside trade in goods, like trade in services, investment, government procurement and intellectual property rights and in this is way similar to other modern free trade agreement. However, practically only significant progress has been only made in trade in goods. Moreover, since Croatia was the most developed country in CEFTA, other member countries served predominantly as export destinations, while imports where relatively subdued.

To the best of our knowledge this is the first paper that addresses this topic for Croatian firms with the database that comprises firm's exports and imports to and from 41 trading partner countries (and more than 90\% of total trade) and that covers such long timespan (13 years). Moreover, our contribution to the existing literature is in the use of dynamic trade model on the product level data. Furthermore, by estimating the gravity model at the product level, that is, we combine microeconomic and macroeconomic data in order to get insight on how changes in the macroeconomic environment affected trade flows at the product level in international trade (taking into consideration problems with estimation of effects of aggregate data on micro units; Moulton, 1990). Finally, we test for the changes in intensive and extensive trade margins at the product level so that we can track effects of variable trade cost changes on different types of import and export trade flows. We emphasize the importance of estimation of the intensive and extensive import margins, since they are often neglected in empirical papers but are of practical importance in the case of highly import-oriented country like Croatia.

Building on previous assessments, the hypothesis of our paper is that RTAs-induced trade liberalization will have heterogeneous effects on particular product groups with indirect implications on national welfare.

The paper is structured as follows. In second section we provide literature review, where the focus is on the advances in the gravity model estimation and its micro-foundations. We connect this strain of literature with the empirical research on the effects of regional trade agreement (RTA) on trade. Third section contains description of the database used, descriptive statistics and explanation of the methodology. Fourth section comprises results of the estimations and their discussion. The final section concludes. 


\section{Literature review}

The gravity model based studies of RTA effects are typically using country level data with databases that included virtually every RTA signed since 1960s (e.g. Frankel et al., 1996; Baier and Bergstrand, 2007; Magee, 2008; Vicard, 2009; Eicher et al., 2012; Baier et al., 2014). In general these studies confirm the trade creating effect of RTAs among the partner countries, while the evidence on trade diversion is more mixed. Reviewing 75 empirical studies and employing metaanalysis approach Cipollina and Salvatici (2010) establish a robust, positive RTA effect, equivalent to an increase in trade exceeding 30\% with increasing tendency in the last years characterized by the dominance of deep and comprehensive agreements.

However, up to 1990s, large portion of empirical literature used country level data - that (highest) level of data aggregation prevented one from exploring more subtle trade details, apart from effects of different exogenous variables on total volume of trade and/or separately exports and imports. From 2000s, transaction level data became widely accessible and empirical papers focusing on industry, firm, and transaction level analysis emerged (Chaney, 2008; Crozet and Koenig, 2010; Eaton et al., 2011; Lawless, 2010; Zaninović and Zajc Kejžar, 2015). First extension of dependent variable in the gravity equation from total exports or imports into intensive (trade volume) and extensive (number of trading partners, number of products traded) margins was proposed by Eaton et al. (2011), where they decomposed total exports on number of exporters and average exports per firm. Subsequent papers took different definitions of intensive and extensive margins, that is, they estimated changes in average exports per product, the number of products being exported per firm, etc. Studies that account for the intensive and extensive margins show that trade liberalisation does not just intensifies existing trade but also causes significant adjustments along the extensive margins (Foster et al., 2011; Markusen, 2013), resulting in greater export/import product variety (Kehoe and Ruhl, 2003; Feenstra and Kee, 2007; Goldberg et al., 2008) and establishing trade relations with new partners (Felbermayr and Kohler, 2007). Further, by focusing on the timing between signing of the integration agreement and its effects on trade margins Baier et al. (2014) showed that intensive margin effects occurs sooner than extensive margin ones (number of products exported). This fact follows logic since the introduction of new products in foreign markets takes time.

Apart from introduction of the trade margins, the primary focus of this new wave of research was in the introduction of firm heterogeneity into trade models (Melitz, 2003). Theoretical and empirical contributions have confirmed the importance of accounting for both fixed cost of exporting, that is, marketspecific fixed/sunk entry costs and variable costs of exporting, e.g. tariff duty 
and transportation costs. In 2008, Chaney introduced heterogeneous firms in gravity model setting and showed that when transportation costs vary, not only does each exporter change the size of its exports (the intensive margin), but the set of exporters varies as well (the extensive margin). Moreover, Chaney found that the elasticity of substitution among goods has opposite effects on each margin. With high substitutability of products intensive margins are expected to be more sensitive to changes in variable costs (e.g. trade barriers), while the effects on extensive margins are subdued. Opposite is the case when there is a low substitutability between products, that is, when market is characterized by high product differentiation. By introducing dynamics in Melitz model, Ruhl (2005) demonstrated that in response to high frequency transitory shocks, most of the adjustments of exports happen at the intensive margin, whereas in response to permanent shocks such as trade liberalization, both the intensive and the extensive margins adjust. Using US firm US export data Lawless (2010) found that fixed and variable trade costs are negatively correlated with the extensive margins, while the effects on intensive margins are not straightforwardly deduced - reduction of variable trade costs can induce market entry of low productivity firms that were below threshold productivity level before cost changes, thus lowering average sales per firm. On the other hand, incumbents will sell more, so the final outcome of the variable cost change effects on intensive margin will depend on which of the two trends is stronger.

Importance of including heterogeneous products according to usage in gravity model setting was recognized by Hayakawa and Yamashita (2011). In their paper, they separately estimate effects of free trade agreements on trade in final (consumption) and intermediate goods. Their findings are that the effects of free trade agreements on trade in intermediates are insignificant in the short term but elastic in the long term (six years), while trade in final goods respond positively and significantly in both short and long term. Considering importance of time dimension when estimating RTAs impact on trade flows, Baier and Bergstrand (2007) use a panel of cross-section time series at five-year intervals from 1960 to 2000. We use similar approach as a robustness check.

Table 1: Estimates of standard gravity variables

\begin{tabular}{|l|c|c|c|c|}
\hline \multirow{2}{*}{ Variables } & \multicolumn{4}{c|}{ Structural gravity models } \\
\cline { 2 - 5 } & median & mean & s.d. & no.est. \\
\hline Origin GDP & 0.86 & 0.74 & 0.45 & 31 \\
\hline Destination GDP & 0.67 & 0.58 & 0.41 & 29 \\
\hline Distance & -1.14 & -1.1 & 0.41 & 328 \\
\hline Contiguity & 0.52 & 0.66 & 0.65 & 266 \\
\hline RTA & 0.28 & 0.36 & 0.42 & 108 \\
\hline
\end{tabular}

Source: Adjusted from Head and Mayer (2014), p. 29 
Since we employ gravity model as a tool in explaining the RTA effects on trade flows and having in mind that this approach is used in a number of papers, in Table 1 we present results of meta-analysis done by Head and Mayer (2014). Their database included 159 papers and more than 2500 estimates of variables that are standardly used in gravity models. We used estimated coefficient in Table 1 as a benchmark (for estimations for all goods, by BEC).

\section{Methodology}

Next sections explain methodology employed used in order to explain changes in trade margins of Croatian firms during observed period as well as the detail explanation of static and dynamic trade models used.

\subsection{Descriptive statistics and trade margins decomposition}

In order to show developments of trade throughout the observed period, we decompose export and import trade margins adopting methodology from Bernard et al. (2009). We separate total trade into three extensive and one intensive margin. This can be shown with the following identity:

$$
\Delta X=\Delta f \Delta i \Delta p \Delta a v g
$$

where total exports - X (we separately decompose total imports as well as the imports classified according to main the BEC product categories), are decomposed on the number of exporters $(f)$, the average number of destination markets (i), average number of products traded $(p)$ and average sales per exporter-productcountry (avg). Delta signs signify that we also compared changes in trade decompositions between years 2000 and 2012. We are practically modifying the approach of Bernard et al. (2009) who did cross-section analysis for United States, in a manner similar to Behrens et al. (2013)'s analysis for Belgian firms. Identity (1) is the basis for the regression decomposition, where we, after taking logs, regress (using ordinary least squares estimation - OLS) separately each of the trade margins on the RHS of decomposition (1) on total trade. Decomposition results are interpreted as the contributions of each of the trade margins to exports and imports during the time span of 13 years.

Table 2 shows that the biggest contribution to cumulative trade growth from 2000 to 2012 comes from extensive margins $(90 \%$ on the export side and $82 \%$ on the import side). This is in line with empirical research for developing and transition economies. For example, from 1975 to 2003, East Asian countries recorded growth rates in export relationships (defined as number of new trading partners) of $369 \%$, while USA and EU-15 recorded growth rates of $17 \%$ and $41 \%$ respectively (Besedeš and Prusa, 2011). 
Table 2: Decomposition of cumulative export and import trade margins, 2000-2012

\begin{tabular}{|l|c|c|c|c|c|c|c|c|}
\hline \multirow{2}{*}{ Margin } & \multicolumn{4}{|c|}{ Exports } & \multicolumn{4}{c|}{ Imports } \\
\cline { 2 - 10 } & $\begin{array}{c}\text { All } \\
\text { products }\end{array}$ & BEC1 & BEC2 & BEC3 & $\begin{array}{c}\text { All } \\
\text { products }\end{array}$ & BEC1 & BEC2 & BEC3 \\
\hline Firms & 0.50 & 0.34 & 0.91 & 0.67 & 0.30 & 0.30 & 0.38 & 0.34 \\
\hline Country & 0.26 & 0.23 & 0.35 & 0.23 & 0.30 & 0.28 & 0.32 & 0.20 \\
\hline Products & 0.14 & 0.09 & 0.14 & 0.16 & 0.22 & 0.18 & 0.19 & 0.17 \\
\hline Intensive & 0.10 & 0.35 & -0.40 & -0.05 & 0.18 & 0.24 & 0.11 & 0.30 \\
\hline Total & 1.00 & 1.00 & 1.00 & 1.00 & 1.00 & 1.00 & 1.00 & 1.00 \\
\hline
\end{tabular}

Note: BEC1 - Intermediate goods; BEC2 - Consumption goods; BEC3 - Capital goods.

Source: Authors' calculations

When observing at BEC product groups level, rise of the number of firms exporting consumption goods $(90 \%)$ and the fall of intensive margin contribution to exports $(-40 \%)$ is noticeable and could indicate high level of competition in consumption goods export sector. When looking at the import trade margins, structure of margins contribution to imports across all BEC product groups is more balanced. This could indicate that main links with foreign suppliers were established before observed period and that firms focussing on imports operate on less competitive domestic market.

\subsection{Gravity model specification}

Seminal paper from Anderson (1979) marked the first attempt of providing microfoundations for the gravity model. Aim of his paper was to provide theoretical explanations for the gravity equation applied to commodities. His model included trade in goods differentiated by the country of origin (Armington assumption/ model) where producers in each country produces one variety of the product and consumers consume portion of the each of the produced commodity (constant elasticity of substitution is assumed). Strict assumptions of the proposed model meant that zero trade (empirical reality) as well as the research of the influences of trade facilitation on the extensive trade margin were much less explored.

Next important milestones were papers by Bergstrand $(1985,1990)$. Bergstrand first included price indexes and exchange rate variables in the gravity equation (1985) and monopolistic competition (1990) in the gravity equation by assuming that countries completely specialize in different product varieties. Anderson and van Wincoop (2003) contributed to the theory of the gravity model by including multilateral resistance term which takes into consideration trade resistance between a country and all other trading partners. Main conclusion is that bilateral trade flows between trading partners " $\mathrm{i}$ " and " $\mathrm{j}$ " depend on the multilateral resistance, that is, they are dependent on all other trading partners of those two countries. Their formulation of the gravity 
equation, which is the basis for almost all subsequent papers that use gravity models in order to explain bilateral trade flows, is the following:

$$
X_{i j t}=\frac{X_{i t} Y_{j t}}{Y_{t}}\left(\frac{t_{i j t}}{\pi_{i t} P_{j t}}\right)^{1-\sigma},
$$

where $Y_{i t}$ and $Y_{j t}$ stand for particular countries and $Y_{t}$ stands for world GDP, while $\mathrm{t}_{\mathrm{ijt}}$ is the tariff equivalent of overall trade costs. Elasticity of substitution between goods is represented with $\sigma$, while $\pi_{i t}$ and $P_{j t}$ represent multilateral resistance terms (in another words - exporter and importer ease of market access). In practice, importer and exporter fixed effects (dummy variables) are usually used in order to capture multilateral resistance terms. In the case of panel data, we needed to use importer-year and exporter-year fixed effects. In equation (2), terms $\pi_{i t}$ and $P_{j t}$, connect general equilibrium theory principles with the gravity model setting. With the introduction of these terms in the equation describing bilateral trade flows, we take into account that each sale and each purchase has multiple destinations (for example, if we neglect zero trade flows and assume $n$ countries, that would mean $(n-1)^{2}$ destinations in the world) and we take into consideration how each bilateral sale/purchase interact with all other bilateral sales/purchases. This kind of model also called structural gravity model (Anderson, 2011).

Following sections explain methodology used in order to explain trade flows on product level where we distinguish between static and dynamic trade model.

\subsubsection{Static model}

Building on (2), we estimate gravity model at product level, that is, we estimate exports/import margins on product level during observed period as a function of RHS variables (RTAs). Among different econometric estimators used in gravity model estimations, we used pooled regression (POLS), fixed effects ${ }^{6}$ (FE) and Poisson Pseudo Maximum Likelihood (PPML) estimator.

In theory, the basic structure of gravity model in aforementioned context is the following ${ }^{7}$ :

$$
y_{i t}=\alpha+x_{i t} \beta_{k}+z_{i} \delta+u_{i}+\varepsilon_{i t}
$$

where, by the assumptions of the model, individual-specific (and time-invariant) effect $\left(u_{i}\right)$ is potentially correlated with the regressors $\left(x_{i t}\right)$. When estimating

\footnotetext{
${ }^{6}$ We used Hausman test and test of over-identifying restrictions in order to see which of the two estimations methods is more suitable - fixed or random effects; results where always in favour of fixed effects.

7 Multiplicative forms of the equations (3) and (4) are assumed for PPML estimation.
} 
equation (3) as FE model, time-invariant variables $\left(z_{i}\right)$ like distance and contiguity are removed together with time-invariant characteristics, although it is possible to obtain estimates of $\delta$ of coefficients by using residuals from FE estimations (Martinez-Zarzoso and Nowak-Lehman, 2003). Term $\varepsilon_{i t}$ stands for idiosyncratic error term. Since in this paper we are focused on and RTAs effect on trade margins, we focus only on $x_{i t} \beta_{k}$ term. Moreover, it should be noted that when equation (3) is estimated as POLS model, individual-specific term goes is in the error term and we substitute $\varepsilon_{i t}$ with $v_{i t}$, where $v_{i t}=u_{i}+\varepsilon_{i t}$.

Apart from POLS and FE, and in order to account for zero trade flows ${ }^{8}$, we employ PPML estimator, that was proposed by Santos Silva and Tenreyro (2006). In comparison with POLS and FE, PPML should give unbiased and consistent estimates.

Thus, the estimated static gravity model the following:

$$
z_{p j t}=\alpha_{0}+\beta_{1} S A A_{j t}+\beta_{2} C E F T A_{j t}+\beta_{j} i s o \times \beta_{t} \text { year }+\varepsilon_{p j t},
$$

where the dependent variable $z_{j p t}$ can be decomposed into the extensive and intensive trade margins:

$$
e_{F L O W p j t}=n_{p j t}+\frac{e_{F L O W} p j t}{n_{p j t}},
$$

where values are expressed in logs (for the PPML we use values in levels) and $e_{F L O W_{p j t}}$ stands for product $p$ exports/imports flows to/from country $j, n_{p j t}$ is a number of firms exporting product $p$ to the destination $j, \frac{e_{F L O W} p j t}{n_{p j t}}$ are product exports/ imports per firm-country. As an example, we are interested in Croatian exports of CN 89039110 (sea-going sailboats and yachts) across different countries $\left(e_{F L O W_{p j t}}\right)$. Also, we are interested in average exports of CN 89039110 per firm that exports that particular product $\left(\frac{e_{F L O W} p j t}{n_{p j t}}\right)$ and finally, number of firms selling that particular product, that is, CN $89039110\left(n_{p j t}\right)$. Error term is noted with $\varepsilon_{p j t}$.

We estimated (4) with lagged RTA effects (one-year lags), since RTA-induced changes in terms of trade tend to have lagged effects on trade, but most importantly to account for endogeneity of RTA variables. Moreover, as robustness check we used data only for every third year and than estimated (4) with one-period lag values of RTA variables.

\footnotetext{
8 Original database obtained from the Croatian Bureau of Statistics was without zero trade flows, that is, panel was unbalanced $(\mathrm{N} \times \mathrm{Ti})$, so we created strongly balanced data $(\mathrm{N} \times \mathrm{T})$ by filling it with the original panel with zeros. Balanced panel contains around $80 \%$ of zeros, which is in line with empirical findings. For example, Baldwin and Harrigan (2011) report similar findings for the case of United States.
} 
When estimating equation for imports we tried adding five more dummy variables for RTA, since the Croatia gradually lowered tariffs on imports from EU. Import duties were first lowered on the $70 \%$ of the basic duty in $2002,50 \%$ in 2003 , $40 \%$ in $2004,30 \%$ in $2005,15 \%$ from 2006 and from the year 2007 remaining duties were abolished for industrial products (liberalization of agricultural group of products ended by 2005). Also, imports of one part of the product set (which included intermediates and consumption goods) was liberalized faster $(60 \%$ of the basic duty from 2002, 30\% from 2003 and from 2004 duties were abolished). We present results only for 2002 as the referent year, since we use three year lags as a robustness check and so we practically cover the period of gradual liberalization of imports from EU.

\subsubsection{Dynamic model}

Since the static linear estimators offer only contemporaneous effects of regressors on trade, we use dynamic linear model for a robustness check. Moreover, we use it also in order to account for endogeneity of regressors (e.g. trade flows should be positively affected by signing of RTA, but RTA could also be signed because of increased trade flows beforehand) and to take into account potential non-stationarity of trade that could cause biased estimates of fixed effects estimator. Specifically, we use two-step Generalized Method of Moments (GMM) estimator derived by Arellano and Bond (1991) and modified by Blundell and Bond (1998), which produces consistent parameter estimates for a finite number of time periods and a large cross-sectional dimension. Estimator uses moment conditions in which lagged levels of dependent variable are instruments for the differenced equations, while lagged differences of dependent variable are used as instruments for equations in levels.

We started building the model considering the basic dynamic panel-data model:

$$
y_{i t}=\sum_{j=1}^{p} \alpha_{j} y_{i, t-1}+x_{i t} \beta_{1}+w_{i t} \beta_{2}+v_{i}+\varepsilon_{i t},
$$

assuming $i=1, \ldots, N$ and $t=1, \ldots, T_{i}$ and where $\alpha_{j}$ and $p$ are parameters to be estimated, $x_{i t}$ is a column vector of strictly exogenous regressors, $w_{i t}$ is a column vector of predetermined and endogenous regressors while $\beta_{1}$ and $\beta_{2}$ are row vectors containing parameters to be estimated. Last two terms represent panel-level effects $\left(v_{i}\right)$ and random disturbance (error) term $\left(\varepsilon_{i t}\right)$. Model assumes that $v_{i}$ and $\varepsilon_{i t}$ are independent for each $i$ over all $t$.

In order to create empirical model, we started from model (6), where we added lagged values of exports (imports) as explanatory variables. Results of the Arellano-Bond test (AB) for serial correlation rejected null hypothesis of no serial correlations in the first-differenced errors at orders one and two, so we tried including two lags of the dependent variable $\left(x_{p j, t-1}\right.$ and $\left.x_{p j, t-2}\right)$ that resulted in 
acceptance of $\mathrm{H}_{0}$ hypothesis of zero autocorrelation between errors at order two for most estimations of the export margins, while the $\mathrm{H}_{0}$ was accepted only at the fourth order. We acknowledge that this is an issue, but we claim that the results are robust because estimations results for both imports and exports margins show stable dynamic relationship between level and lagged trade flows, that is, $\beta_{1}+\beta_{2}<1$ (Bun and Klaassen, 2002). Moreover, for the estimations of dynamic model for the import margins we draw smaller samples (2.000) without gaps within panel units from original dataset (714.000) and obtained the results for $\mathrm{AB}$ test that where in line with expectations.

Thus, the model that was estimated is the following:

$$
\begin{aligned}
x_{p j t}= & \alpha_{0}+\Sigma_{k=1}^{2} \beta_{k} x_{p j, t-k}+\beta_{2} g d p_{j t}+\beta_{3} S A A_{j t}+\beta_{4} C E F T A_{j t}+\beta_{5} \text { dist }_{j t}+ \\
& +\beta_{6} \text { contig }_{j t}+\beta_{j} i s o+\beta_{t} \text { year }+\varepsilon_{p j t},
\end{aligned}
$$

We estimated equation (7) for both export and import trade margins. Explanation of the dependent variables is the same as in (4), while for the independent variables we use following notation $-g d p_{j t}$ stands for nominal GDP of trading partner, dist $t_{j}$ and contig $_{j}$ for distance between trade partners capital cities and contiguity ( 1 if country $j$ shares a common border with Croatia) respectively, while $S A A_{j t}$ and $C E F T A_{j t}$ are dummy variables with the value of 1 if the free trade agreement is implemented between Croatia and EU or CEFTA countries. We note country and time fixed effects with $\beta_{j} i$ so and $\beta_{t}$ year, respectively. We added standard gravity variables in the dynamic model in order to use them as instruments in estimations, since it was impossible to obtain results from estimating equation (7) with country-year $\mathrm{FE}^{9}$. We also tried to employ same procedure as with the static model, that is, use data for every third year, but the results and diagnostic test were not attainable.

Instruments for first differences equation were values of first-differenced GDP and first and second lags of dependent variable, while instruments for levels equations where country and time fixed effects, lagged values of RTAs (we restrict the number of lags used for instrumenting up to two), contiguity and distance as well as first and second differences of dependent variable.

Regarding Sargan and Hansen tests of over-identifying restrictions that are reported by default after xtabond 2 command that was used (all models, both static and dynamic were run in Stata 13); since we practically have 61 RHS variables (41 variables representing country fixed effects, 13 variables representing time fixed effects and 7 other RHS variables as described in (6)) and the number of instruments is 110 , we have roughly 49 over-identifying restrictions per estimation

\footnotetext{
9 We highlight this fact because our paper is focused on estimation of trade margins using structural gravity model, while the standard gravity variables are only tools that we use in order to estimate equation (7).
} 
(number of moments minus number of RHS variables). That fact paired with highly heterogeneous panel level unit caused rejection of the $\mathrm{H}_{0}$ (that the overidentification restrictions/instruments are valid). Even Arellano-Bond (1991: 291) warned of over rejection problem for the Sargan test. We tried lowering the number of instruments by replacing GMM instruments with their principal components (that decreased the number of instruments by 20 on average) but that that did $t$ led to accepting the $\mathrm{H}_{0}$ for the Hansen test ${ }^{10}$. Results of these tests are available upon request. Of course, important issue is also impossibility to find proper instruments other than those contained within the set of (the lagged values of) explanatory variables that would be correlated with RTAs variable (instruments are weak). This is longstanding issue in this field of research (international trade - RTA link). On the top of all, number of instruments should be equal or lower than the number of groups (panel level units) and any deviation from that "rule of thumb", either that the number of instruments is greater than the number of groups or opposite - that the number of instruments is lot lower than the number of groups (110 instruments and more than 20.000 groups on average) causes problems with both Sargan and Hansen tests (Roodman, 2009).

\section{Empirical data and analysis}

Trade data was obtained from Croatian Bureau of Statistics and includes firmlevel data on exports and imports of goods for Croatian firms from 2000 up to 2012. Sample includes bilateral trade flows between Croatian firms and 41 countries and represents more than $90 \%$ of total trade during observed period. Out of the 41 countries, 36 are European countries (27 EU member states, Western Balkans ${ }^{11}$ countries, Turkey and Switzerland) and 5 are from rest of the world (China, Japan, Russia, South Korea and United States). Due to geographical concentration on the European countries in our sample, the estimated regression coefficient on the distance variable (see $\beta_{5}$ in equation (7)) might be biased (especially for the imports since imports from China and U.S. have been rising steadily from the early 2000s).

Firms are classified according to 2-digit National Classification of Activities (2007 version) while products are classified according to 8-digit Combined Nomenclature $(\mathrm{CN})$. For decomposition described in the following section we use firm level data while for the purposes of estimation of both static and dynamic product level gravity models we summed all firms exports and imports on 8-digit CN level.

\footnotetext{
${ }^{10}$ Only when the number of instruments surpassed the number of regressors by only three (3) did the Hansen test accepted $\mathrm{H}_{0}$, but estimation of equation (7) in that way (without country and time dummies) does not follow trade gravity theoretic propositions.

${ }^{11}$ Albania, Bosnia and Herzegovina, the former Yugoslav Republic of Macedonia, Montenegro, Serbia, Kosovo.
} 
Using 8-digit $\mathrm{CN}$ we sorted products into three BEC product categories, namely intermediate (BEC1), consumption (BEC2) and capital goods (BEC3). Gross domestic product (nominal, at market prices) data were taken from Eurostat, distance between country capitals (trade cost proxy) is taken from the Centre d'Études Prospectives et d'Informations Internationales (CEPII) database, while relevant years according to which dummy variables for free trade agreements were defined were taken from official journals (NN, 14/2001). Cut-off value for trade flows at the product level is 1000 euros.

Results of the estimations of static model using PPML are given in Tables 3 through 6.

Table 3: Results of the Poisson estimation with one-year lagged RTA variables for export and import intensive trade margin

\begin{tabular}{|c|c|c|c|c|c|}
\hline \multirow{2}{*}{ Ind. var. } & EXP_VAL & EXP_VAL & IMP_VAL & IMP_VAL & IMP_VAL \\
\hline & BEC1 & BEC2 & BEC1 & BEC2 & BEC3 \\
\hline \multirow[t]{2}{*}{ L.SAA } & 0.457 & $1.789^{* *}$ & $2.360^{* * *}$ & $6.064^{* * *}$ & 1.073 \\
\hline & $(0.634)$ & $(0.718)$ & $(0.594)$ & $(0.641)$ & $(0.966)$ \\
\hline \multirow[t]{2}{*}{ L.CEFTA } & $1.634^{* * *}$ & $2.534^{* * *}$ & $3.217^{* * *}$ & $6.220 * * *$ & 0.372 \\
\hline & $(0.567)$ & $(0.708)$ & $(0.595)$ & $(0.595)$ & $(0.975)$ \\
\hline \multirow[t]{2}{*}{ Constant } & $9.593^{* * *}$ & $8.287^{* * *}$ & $7.656^{* * *}$ & $4.491^{* * *}$ & $9.170^{* * *}$ \\
\hline & $(0.545)$ & $(0.689)$ & $(0.572)$ & $(0.567)$ & $(0.946)$ \\
\hline Country-year FE & Yes & Yes & Yes & Yes & Yes \\
\hline Observations & 539,592 & 316,644 & $1,013,628$ & 537,084 & 358,716 \\
\hline
\end{tabular}

Note: Estimations across BEC categories, 2000-2012. Letter L before regional trade agreements (RTA) dummies stands for one-year lag; EXP_VAL and IMP_VAL are abbreviations for values of exports and imports, respectively; abbreviations for other variables are explained in section 3.2.1.

Robust standard errors in parentheses ${ }^{* * *} \mathrm{p}<0.01,{ }^{* *} \mathrm{p}<0.05,{ }^{*} \mathrm{p}<0.1$.

Source: Authors' calculations

Estimated parameter of the intensive export margin (Table 3) for capital goods is not reported since it could not be estimated due to convergence issue (probably caused by large number of zeros in the sample). 
Katja Zajc Kejžar, Črt Kostevc, Vinko Zaninović • The role of regional economic...

Table 4: Results of the Poisson estimation with three-year lagged RTA variables for export and import intensive trade margin

\begin{tabular}{|c|c|c|c|c|c|c|}
\hline \multirow{2}{*}{ Ind. var. } & EXP_VAL & EXP_VAL & EXP_VAL & IMP_VAL & IMP_VAL & IMP_VAL \\
\hline & BEC1 & $\mathrm{BEC} 2$ & BEC3 & $\mathrm{BEC1}$ & BEC2 & $\mathrm{BEC} 3$ \\
\hline \multirow[t]{2}{*}{ L3.SAA } & -0.137 & 0.619 & $1.717^{*}$ & $2.327^{* * *}$ & $4.075^{* * *}$ & $1.891^{* *}$ \\
\hline & $(0.570)$ & $(0.802)$ & $(1.014)$ & $(0.581)$ & $(0.426)$ & $(0.875)$ \\
\hline \multirow[t]{2}{*}{ L3.CEFTA } & $1.041^{* *}$ & $1.364^{*}$ & 1.350 & $3.185^{* * *}$ & $4.231^{\text {*** }}$ & 1.190 \\
\hline & $(0.494)$ & $(0.793)$ & $(0.878)$ & $(0.582)$ & $(0.353)$ & $(0.885)$ \\
\hline \multirow[t]{2}{*}{ Constant } & $10.19^{* * *}$ & $9.457^{* * *}$ & $9.280^{* * *}$ & $7.689^{* * *}$ & $6.480^{* * *}$ & $8.352^{* * *}$ \\
\hline & $(0.469)$ & $(0.776)$ & $(0.802)$ & $(0.559)$ & $(0.304)$ & $(0.854)$ \\
\hline Country-year FE & Yes & Yes & Yes & Yes & Yes & Yes \\
\hline Observations & 179,864 & 105,548 & 75,228 & 337,876 & 179,028 & 119,572 \\
\hline
\end{tabular}

Note: Estimations across BEC categories, 2000-2012. String L3 before regional trade agreements (RTA) dummies stands for three-year lag; EXP_VAL and IMP_VAL are abbreviations for values of exports and imports, respectively; explanation of abbreviations for independent variables is given in section 3.2.1. We use only data for every third year.

Robust standard errors in parentheses ${ }^{* * *} \mathrm{p}<0.01,{ }^{* *} \mathrm{p}<0.05,{ }^{*} \mathrm{p}<0.1$.

Source: Authors' calculations

Results from estimations of the static model using POLS and FE are given in Tables A3 through A5 (in Appendix). Estimation results for dynamic model are in Tables $\mathrm{A} 2$ and $\mathrm{A} 3$. Acronyms BEC1, BEC2 and BEC3 were used to distinguish between intermediate, consumer and capital goods respectively, while independent variables are in the rows (Ind. var.), while dependent variables are in the columns (Dep. var.).

Table 5: Results of the Poisson estimation with one-year lagged RTA variables for export and import extensive trade margin

\begin{tabular}{|l|c|c|c|c|c|c|}
\hline \multirow{2}{*}{ Ind. var. Dep. var. } & $\mathrm{ID}(\mathrm{X})$ & $\mathrm{ID}(\mathrm{X})$ & $\mathrm{ID}(\mathrm{X})$ & $\mathrm{ID}(\mathrm{M})$ & $\mathrm{ID}(\mathrm{M})$ & $\mathrm{ID}(\mathrm{M})$ \\
\cline { 2 - 7 } & $\mathrm{BEC} 1$ & $\mathrm{BEC} 2$ & $\mathrm{BEC} 3$ & $\mathrm{BEC} 1$ & $\mathrm{BEC} 2$ & $\mathrm{BEC} 3$ \\
\hline L.SAA & $2.105^{* * *}$ & $2.103^{* * *}$ & $2.007^{* * *}$ & $2.852^{* * *}$ & $4.559^{* * *}$ & $2.374^{* * *}$ \\
\hline & $(0.213)$ & $(0.223)$ & $(0.342)$ & $(0.549)$ & $(0.526)$ & $(0.391)$ \\
\hline L.CEFTA & $3.422^{* * *}$ & $3.213^{* * *}$ & $3.866^{* * *}$ & $2.824^{* * *}$ & $4.898^{* * *}$ & $2.527^{* * *}$ \\
\hline & $(0.194)$ & $(0.213)$ & $(0.313)$ & $(0.548)$ & $(0.502)$ & $(0.396)$ \\
\hline Constant & $-2.822^{* * *}$ & $-2.749^{* * *}$ & $-3.296^{* * *}$ & $-2.155^{* * *}$ & $-4.115^{* * *}$ & $-2.100^{* * *}$ \\
\hline & $(0.188)$ & $(0.197)$ & $(0.307)$ & $(0.546)$ & $(0.496)$ & $(0.382)$ \\
\hline Country-year FE & Yes & Yes & Yes & Yes & Yes & Yes \\
\hline Observations & 539,592 & 316,644 & 225,684 & $1,013,628$ & 537,084 & 358,716 \\
\hline
\end{tabular}

Note: Estimations across BEC categories, 2000-2012. Letter L before regional trade agreements (RTA) dummies stands for one-year lag; ID(X) and ID(M) are abbreviations for the number of firms exporting particular CN8 product, respectively; explanation of abbreviations for independent variables is given in section 3.2.1.

Robust standard errors in parentheses ${ }^{* * *} \mathrm{p}<0.01{ }^{* *} \mathrm{p}<0.05,{ }^{*} \mathrm{p}<0.1$.

Source: Authors' calculations 
Estimates in Tables 5 and 6 are of particular interest, since the Poisson estimator is generally used with count data as dependent variables, so it is particularly suited for the estimation of the effects of RTAs on the number of firms exporting and importing particular product.

Table 6: Results of the Poisson estimation with three-year lagged RTA variables for export and import extensive trade margin

\begin{tabular}{|l|c|c|c|c|c|c|}
\hline \multirow{2}{*}{ Ind. var. } & $\mathrm{ID}(\mathrm{X})$ & $\mathrm{ID}(\mathrm{X})$ & $\mathrm{ID}(\mathrm{X})$ & $\mathrm{ID}(\mathrm{M})$ & $\mathrm{ID}(\mathrm{M})$ & $\mathrm{ID}(\mathrm{M})$ \\
\cline { 2 - 7 } & $\mathrm{BEC} 1$ & $\mathrm{BEC} 2$ & $\mathrm{BEC} 3$ & $\mathrm{BEC} 1$ & $\mathrm{BEC} 2$ & $\mathrm{BEC} 3$ \\
\hline L3.SAA & $1.234^{* * *}$ & $1.755^{* * *}$ & $0.803^{* * *}$ & $1.987^{* * *}$ & $2.074^{* * *}$ & $2.374^{* * *}$ \\
\hline & $(0.156)$ & $(0.198)$ & $(0.236)$ & $(0.320)$ & $(0.322)$ & $(0.391)$ \\
\hline L3.CEFTA & $2.551^{* * *}$ & $2.864^{* * *}$ & $2.662^{* * *}$ & $1.959^{* * *}$ & $2.413^{* * *}$ & $2.527^{* * *}$ \\
\hline & $(0.128)$ & $(0.186)$ & $(0.192)$ & $(0.318)$ & $(0.281)$ & $(0.396)$ \\
\hline Constant & $-1.951^{* * *}$ & $-2.401^{* * *}$ & $-2.092^{* * *}$ & $-1.290^{* * *}$ & $-1.630^{* * *}$ & $-2.100^{* * *}$ \\
\hline & $(0.120)$ & $(0.169)$ & $(0.182)$ & $(0.315)$ & $(0.271)$ & $(0.382)$ \\
\hline Country-year FE & Yes & Yes & Yes & Yes & Yes & Yes \\
\hline Observations & 179,864 & 105,548 & 75,228 & 337,876 & 179,028 & 119,572 \\
\hline
\end{tabular}

Note: Estimations across BEC categories, 2000-2012. String L3 before regional trade agreements (RTA) dummies stands for three-year lag; ID(X) and ID(M) are abbreviations for the number of firms exporting particular CN8 product, respectively; abbreviations for other variables are explained in section 3.2.1. We use only data for every third year.

Robust standard errors in parentheses ${ }^{* * *} \mathrm{p}<0.01,{ }^{* *} \mathrm{p}<0.05,{ }^{*} \mathrm{p}<0.1$.

Source: Authors' calculations

The results from Tables 5 and 6 clearly indicate that the import extensive margin for consumption goods in the short run, shows the largest elasticity, while in the long term, its elasticity is similar to that of other goods. Regradless the fact that this is not in line with theoretical expectations, it shows a strong import orientation of Croatian firms

\section{Results and discussion}

Results of estimation of the structural gravity model show unambiguously positive and significant effects of RTAs on trade margins throughout the observed period. Results of the estimation of equation (4), using PPML estimator show significantly (Tables 3 through 6) higher parameter values than those for POLS and FE. We attribute significant difference between POLS and FE on the on side and PPML on the other to the inclusion of zeros in the estimation. Results confirm stronger effects of both RTAs on import margin (trade per product) than on export margins. Results do not change even when we modify our sample and use threeyear lag of RTA variables. When observing the impact of RTAs on particular 
product group, strongest effect is noted for consumption goods. Moreover, this effect is still twice as larger as for other product groups when three-year lag is considered. RTAs impact on extensive margin is largest for the first specification of the equation (4), that is, when one-year lagged values are considered, with the CEFTA effects are over performing FTA effects in both short and long terms (three-year lag).

When comparing results of PPML with the results of POLS and FE in Tables A3-A5, we can see that results are similar in the sense that they are positive and significant, but parameters have lower values. In this case mean value of RTAs effects on intensive margins is around $64 \%$ while $30 \%$ for the export margin.

Generally, in larger portion of estimations, static models confirms that RTAs have disparate effect on different product groups across intensive and extensive trade margins, namely, intensive margins effects are more sensitive for consumer goods, while extensive margin is more sensitive for intermediates and capital goods which is in line with our hypothesis.

Results of the dynamic model (Tables A1-A2), that we used as a robustness check for static models, showed that both RTAs had positive impact on both export and import trade margins (when all products, without differentiation using BEC are considered) in all but one estimations of the equation (7) (estimated parameter value of $S A A$ variable for the case of extensive import margins is negative and insignificant). When looking at the results of the intensive margins estimation for different product groups, the effect of trade liberalization between Croatia and EU is greater for the consumer goods, for both exports and imports.

On the other hand, results of the impact of CEFTA agreement on both exports and imports show that liberalization effects where higher for intermediate and capital goods than for consumption goods. Partly, explanation of these results could be found in the fact that demand and supply structure for the consumption goods is more oriented toward developed countries of the EU, while the economic relationship with the rest of CEFTA member countries is more complex, since most CEFTA countries formed former Yugoslavia. It is plausible to assume that production networks between former Yugoslavia countries that existed before 1990s began to recover in 2000s (for example, number of firm importing from other CEFTA members increased by $46 \%$ ).

Analysis of the results for extensive margins shows significant positive effects of trade liberalization caused by both trade agreements in the case of exports (increase in the number of firms selling particular product was noted only for firms exporting intermediate goods in the case of SAA, while the effects of CEFTA are evenly disbursed across product groups), while results for the imports show positive and significant effects of CEFTA, while SAA effect is nonsignificant. 
Traditional gravity variables (GDP, distance, contiguity) included in the estimations of the dynamic model generally have signs that are somewhat in line with theoretical predictions, although intensive export margins show greater alignment to expected signs than those for import margins, for example, GDP variable has mostly positive signs and is significant, while distance has negative signs (also significant) for the intensive export margins. This suggest significant influence of trade partner's business cycles for export sector (but again, mostly on the intensive margin), while import sector is largely unscathed by the fluctuations of foreign business cycles. Signs and significance for import intensive margins shows higher degree of variation when compared to results of the static models. Stark differences in coefficient signs for imports, when comparing static and dynamic models, can be attributed to the fact that due to the loss of 3 observations for each panel unit in dynamic model (due to estimation methods, that is using lags as instruments), sample on which dynamic model is estimated is significantly different from static models sample.

When comparing SAA and CEFTA effects on trade margins for both static and dynamic models, CEFTA has more impact in trade with intermediates and capital goods (CEFTA effects is stronger when country year FE are included), that is, on total exports/imports per product, average exports/imports per firm and the number of firms that began exporting/importing. This is in line with the fact that Croatia, a the most developed country in the region, used free market access on less competitive market with respect to EU.

\section{Conclusions}

Estimation results of both static and dynamic models confirmed our hypothesis, that is, trade liberalization during 2000s had heterogeneous impact on analysed products groups, as well as on different trade margins. We show, for the case of Croatia, that lowering of variable trade costs via trade liberalization has strongest effects on intensive margins, and that trade in consumption goods was most affected by trade liberalization. This is due to the higher substitution effect in consumer goods market when compared with intermediate and consumption goods markets, where there is higher degree of complementarity between goods. Furthermore, for the extensive trade margin estimation using dynamic model, our results are in line with existent empirical findings, that is, that variable trade costs are negatively correlated with the extensive margins. Contribution of the obtained results to the economic science is in the finding that both symmetric and asymmetric RTAs have significant effects on trade margins of particular country. Furthermore, when comparing SAA and CEFTA effects, both intensive and extensive margins showed higher sensitivity to CEFTA-induced trade liberalization with respect to SAA effects. In the Croatia case, trade with CEFTA contributes to the lowering of long-term trade deficit which has been mostly caused by the unbalanced trade flows with EU member 
states. Proof of CEFTA importance for Croatia's international trade sector can be found in the negative effects (particularly for exporting sector) of the short term abandonment of traditional trade principle with Bosnia and Herzegovina due to Croatia's EU accession in 2013. In the post accession period of Croatia, domestic policy makers should try to keep the preferential status of Croatia within the CEFTA market, given its importance to the Croatian economy. Most important limitation of the research is the fact that the database does not contain any RHS variable on the product level. Having such variable(s) would allow to account for larger portion of heterogeneity between panel units. Future research should be based on integrated database, containing both trade and financial data at the firm level, which will enable researches to account firm-specific factors that effects trade of particular products on the foreign markets. Finally, obtained results show that existent EU trade policy towards one of the Western Balkans countries has significant impact on development of trade, but in future, more focus should be given on balanced trade growth, that is, exports of Western Balkan countries to EU should be more promoted in order to avoid extreme trade imbalances that have negative effects on domestic real and financial sector.

\section{References}

Anderson, J. E. (1979) "A Theoretical Foundation for the Gravity Equation", The American Economic Review, Vol. 69, No. 1, pp. 106-116.

Anderson, J. E. (2011) "The Gravity Model”, Annual Review of Economics, Annual Reviews, Vol. 3, No. 1, pp. 133-160, doi: 10.1146/annurev-economics-111809125114.

Arellano, M., Bond, S. (1991) "Some Tests of Specification for Panel Data: Monte Carlo Evidence and an Application to Employments Equations", The Review of Economic Studies, Vol. 58, No. 2, pp. 277-297, doi: 10.2307/2297968.

Baier, S. L., Bergstrand, J. H. (2007) "Do free trade agreements actually increase members' international trade?", Journal of International Economics, Vol. 71, No. 1, pp. 72-95, doi: 10.1016/j.jinteco.2006.02.005.

Baier, S. L., Bergstrand, J. H., Feng, M. (2014) "Economic integration agreements and the margins of international trade", Journal of International Economics, Vol. 93, No. 2, pp. 339-350, doi: 10.1016/j.jinteco.2014.03.005.

Baldwin, R., Harrigan, J. (2011) "Zeros, Quality, and Space: Trade Theory and Trade Evidence", American Economic Journal: Microeconomics 3, Vol. 3, No. 2, pp. 60-88, doi: 10.1257/mic.3.2.60.

Behrens, K., Corcos, G., Mion, G. (2013) “Trade Crisis? What Trade Crisis?", The Review of Economics and Statistics, Vol. 95, No. 2, pp. 702-709, doi: 10.1162/ rest_a_00287. 
Bergstrand, J. H. (1985) "The Gravity Equation in International Trade: Some Microeconomic Foundations and Empirical Evidence", The Review of Economics and Statistics, Vol. 67, No. 3, pp. 474-481, doi: 10.2307/1925976.

Bergstrand, J. H. (1990) "The Heckscher-Ohlin-Samuelson Model, the Linder Hypothesis, and the Determinants of Bilateral Intra-Industry Trade", The Economic Journal, Vol. 100, No. 403, pp. 1216-1229, doi: 10.2307/2233969.

Bernard, A. B. et al. (2009) "The Margins of US Trade", The American Economic Review, Vol. 99, No. 2, pp. 487-493, doi: 10.2139/ssrn.1602028.

Besedeš, T., Prusa, T. J. (2011) "The role of extensive and intensive margins and export growth", Journal of Development Economics, Vol. 96, No. 2, pp. 371379, doi: 10.1016/j.jdeveco.2010.08.013.

Blundell, R., Bond, S. (1998) "Initial conditions and moment restrictions in dynamic panel data models", Journal of Econometrics, Vol. 87, No. 1, pp. 115-143, doi: 10.1016/s0304-4076(98)00009-8.

Broda, C., Weinstein, D. E. (2006) "Globalization and the Gains from Variety", Quarterly Journal of Economics, Vol. 121, No. 2, pp. 541-585, doi: 10.1162/ qjec.2006.121.2.541.

Bun, M. J. G., Klaassen, F. J. G. M. (2002) "The Importance of Dynamic in Panel Gravity Models of Trade", FEB: Amsterdam School of Economics Research Institute, Discussion Paper: 2002/18, doi: 10.2139/ssrn.306100.

Chaney, T. (2008) "Distorted Gravity: The Intensive and Extensive Margins of International Trade", American Economic Review, Vol. 98, No. 4, pp. 17071721, doi: 10.1257/aer.98.4.1707.

Cipollina, M., Salvatici, L. (2010) "Reciprocal Trade Agreements in Gravity Models: A Meta-Analysis", Review of International Economics, Wiley Blackwell, Vol. 18, No. 1, pp. 63-80, doi: 10.1111/j.1467-9396.2009.00877.x.

Eaton, J., Kortum, S. (2001) "Trade in capital goods", European Economic Review, Vol. 45, No. 7, pp. 1195-1235, doi: 10.1016/s0014-2921(00)00103-3.

Eaton, J., Kortum, S., Kramarz, F. (2011) "An anatomy of international trade: evidence from French firms", Econometrica, Vol. 79, No. 5, pp. 1453-1498, doi: $10.3982 /$ ecta 8318 .

Eicher, T. S., Henn, C., Papageorgiou, C. (2012) "Trade creation and diversion revisited: Accounting for model uncertainty and natural trading partner effects", Journal of Applied Econometrics, Vol. 27, No. 2, pp. 296-321, doi: 10.1002/ jae. 1198 .

Feenstra, R., Kee, H. L. (2007) "Trade Liberalisation and Export Variety: A Comparison of Mexico and China", The World Economy, Vol. 30, No. 1, pp. 5-21, doi: 10.1111/j.1467-9701.2007.00869.x.

Felbermayr, G. J., Kohler, W. (2007) "Does WTO Membership Make a Difference at the Extensive Margin of World Trade?", CESifo Working Paper Series 1898, doi: 10.1057/9780230250826_9. 
Foster, N., Poeschl, J., Stehrer, R. (2011) "The Impact of Preferential Trade Agreements on the margins of international trade", Economic Systems, Vol. 35, No. 1, pp. 84-97, doi: 10.1016/j.ecosys.2010.11.004.

Frankel, J. A., Stein, E., Wie, S. J. (1996) "Regional Trading Arrangements: Natural or Supernatural?", National Bureau of Economic Research, Working Paper 5431, doi: 10.3386/w5431.

Frensch, R. (2010) "Trade Liberalization and Import Margins", Emerging Markets Finance and Trade, Vol. 46, No. 3, pp. 4-22, doi: 10.2753/ree1540496x460301.

Goldberg, P. K. et al. (2008) "Multi-product Firms and Product Turnover in the Developing World: Evidence from India", CEPR Discussion Papers 6881, doi: $10.3386 /$ w14127.

Grossman, G., Helpman, E. (1991) Innovation and growth in the global economy, Cambridge: MIT.

Head, K., Mayer, T. (2014) Gravity Equations: Workhorse, Toolkit, and Cookbook, Handbook of International Economics, Elsevier, Vol. 4, pp. 131-195, doi: 10.1016/b978-0-444-54314-1.00003-3.

Helpman, E., Melitz M., Rubinstein, Y. (2008) "Trading partners and trading volumes", Quarterly Journal of Economics, Vol. 123, No. 2, pp. 441-487, doi: 10.1162/qjec.2008.123.2.441.

Jones, C. I. (2008) "Intermediate Goods, Weak Links, and Superstars: A Theory of Economic Development", Working Paper No. 13834, National Bureau of Economic Research, doi: 10.3386/w13834.

Kehoe, T. J., Ruhl, K. J. (2003) "Recent Great Depressions: Aggregate Growth in New Zealand and Switzerland", New Zealand Economic Papers, Vol. 37, No. 1, pp. 5-40, doi: 10.1080/00779950309544377.

Lawless, M. (2010) "Deconstructing gravity: trade costs and extensive and intensive margins", Canadian Journal of Economics, Vol. 43, No. 4, pp. 1149-1172, doi: 10.1111/j.1540-5982.2010.01609.x.

Markusen, J. R. (2013) "Expansion of trade at the extensive margin: a general gains-from-trade result and illustrative examples", Journal of International Economics, Vol. 89, No. 1, pp. 262-270, doi: 10.1016/j.jinteco.2012.04.007.

Martinez-Zarzoso, I., Nowak-Lehmann, F. (2003) "Augmented gravity model: An empirical application to Mercosur-European Union trade flows", Journal of Applied Economics, Vol. 6, No. 2, pp. 291-316.

Melitz, M. J. (2003) "The Impact of Trade on Intra-Industry Reallocations and Aggregate Industry Productivity", Econometrica, Vol. 71, No. 6, pp. 16951725, doi: 10.1111/1468-0262.00467.

Moulton, B. R. (1990) "An Illustration of a Pitfall in Estimating the Effects of Aggregate Variables on Micro Units", The Review of Economics and Statistics, Vol. 72, No. 2, pp. 334-338, doi: 10.2307/2109724. 
Roodman, D. (2009) "A Note on the Theme of Too Many Instruments", Oxford Bulletin of Economics and Statistics, Vol. 71, No. 1, pp. 135-158, doi: 10.1111/j.1468-0084.2008.00542.x.

Ruhl, K. J. (2005) "Solving the Elasticity Problem Puzzle in International Economics", Working Paper, Texas, Austin.

Santos Silva, J. M. C., Tenreyro, S. (2006) "The Log of Gravity", The Review of Economics and Statistics, Vol. 88, No. 4, pp. 641-658, doi: 10.1162/rest.88.4.641.

Tinbergen, J. (1962) Shaping the World Economy - Suggestions for an International Economic Policy, New York: The Twentieth Century Fund.

Vicard, V. (2009) "On trade creation and regional trade agreements: does depth matter?", Review of World Economics (Weltwirtschaftliches Archiv), Vol. 145, No. 2, pp. 167-187, doi: 10.1007/s10290-009-0010-9.

Viner, J. (1950) The Customs Union Issue, New York: Carnegie Endowment for International Peace.

Zaninović, V., Zajc Kejžar, K. (2015) "Intensive and extensive margins of Croatia manufacturing exports: evidence from 2000-2012 period", Cooperation challenges after the EU accession of Croatia, Conference Proceedings (Kumar, A, editor) Ljubljana: ECSA Slovenia, pp. 37-48. 


\title{
Uloga regionalnih ekonomskih integracija na trgovinske marže: slučaj Hrvatske
}

\author{
Katja Zajc Kejžar ${ }^{1}$, Črt Kostevc ${ }^{2}$, Vinko Zaninovic ${ }^{3}$
}

\begin{abstract}
Sažetak
Cilj ovog rada je istražiti razvoj intenzivnih i ekstenzivnih trgovinskih marži na razini proizvod-država za slučaj Hrvatske od 2000. do 2012. godine. Hipoteza istraživanja je da će liberalizacija trgovine, potaknuta sklapanjem regionalnih trgovinskih sporazuma, imati heterogene učinke na različite skupine proizvoda, uz indirektne učinke na nacionalno blagostanje. Koristi se statički $i$ dinamički gravitacijski model koji se primjenjuje na panel podatke koji obuhvaćaju preko 90\% ukupne trgovine u promatranom razdoblju. Ocjene gravitacijskog modela pokazuju da, iako su SAA i CEFTA sporazumi imali pozitivne učinke na intenzivne i ekstenzivne trgovinske marže, posebice na izvoz i uvoz potrošačkih proizvoda, učinci na trgovinu intermedijarnim i kapitalnim dobrima su relativno ograničeni. To ukazuje da su navedeni sporazumi imali snažniji učinak na zadovoljenje potreba potrošača, a ne na porast učinkovitosti domaćeg trgovinskog sektora. Pri usporedbi rezultata učinaka sporazuma koristeći dinamički model, jasan je snažniji utjecaj SAA sporazuma na potrošačka dobra, dok su učinci CEFTA sporazuma ujednačeni za sve skupine dobara. Zaključak je da bi se, u srednjem roku, nositelji hrvatske vanjske politike trebali izboriti za preferencijalni status Hrvatske na CEFTA tržištu, uzimajući u obzir njegovu važnost za hrvatsko gospodarstvo.
\end{abstract}

Ključne riječi: trgovinske marže, gravitacijski model, sporazum o slobodnoj trgovini, Hrvatska

JEL klasifikacija: F10, F12, F15

${ }^{1}$ Izvanredna profesorica, Sveučilište u Ljubljani, Ekonomski fakultet, Kardeljeva ploščad 17, 1000 Ljubljana, Slovenija. Znanstveni interes: međunarodna ekonomija. Tel.: +386 15892 643. E-mail: katja.zajc@ef.uni-lj.si.Osobnaweb stranica: http://www.ef.uni-lj.si/person/Katja-Zajc-Kejzar.

${ }^{2}$ Izvanredni profesor, Sveučilište u Ljubljani, Ekonomski fakultet, Kardeljeva ploščad 17, 1000 Ljubljana, Slovenija. Znanstveni interes: međunarodna ekonomija. Tel.: +386 15892 643. E-mail: crt.kostevc@ef.uni-lj.si.Osobnaweb stranica: http://www.ef.uni-lj.si/person/Crt-Kostevc.

${ }^{3}$ Asistent, Sveučilište u Rijeci, Ekonomski fakultet, Ivana Filipovića 4, 51000 Rijeka, Hrvatska. Znanstveni interes: međunarodna ekonomija.Tel.: +38551355162.E-mail:vinko.zaninovic@ efri.hr. Osobna web stranica: https://www.efri.uniri.hr/personnel/asistent/zaninovic-vinko (autor za korespodenciju). 

Katja Zajc Kejžar, Črt Kostevc, Vinko Zaninović • The role of regional economic...

\section{Appendices}



Katja Zajc Kejžar, Črt Kostevc, Vinko Zaninović • The role of regional economic...

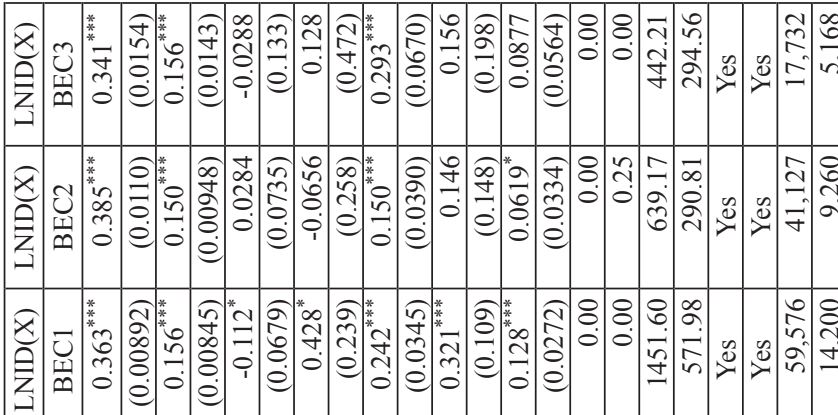

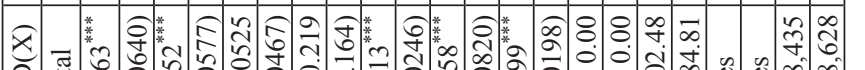

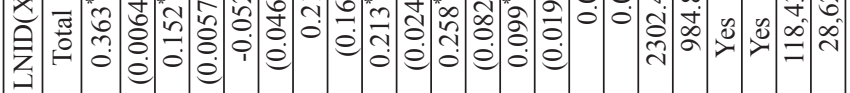

س

齐

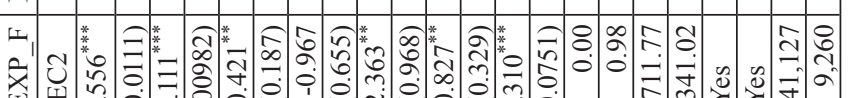

苍导

递

$\sum^{\infty}$ 으

흐

㟒莺

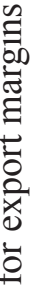

罗

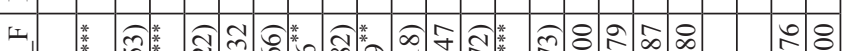

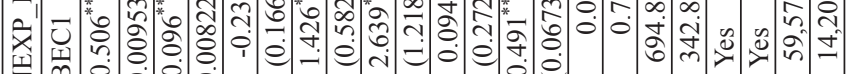

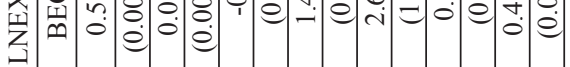

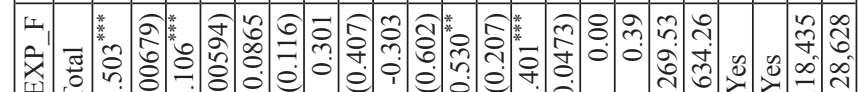

$\sum_{0}$

Фี

is

4

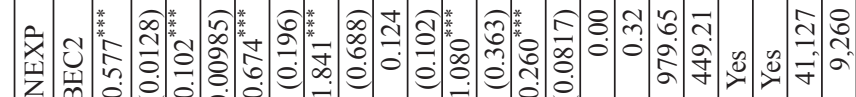

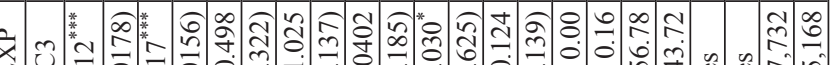

至

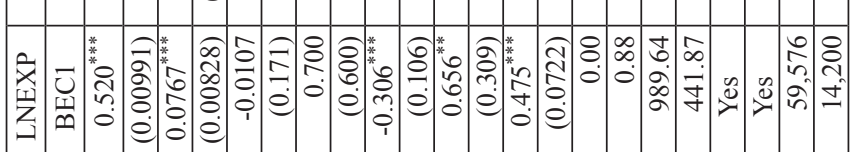

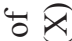

营会

究

幽.

$\stackrel{3}{\frac{\pi}{3}}$

चे

实

के :

莺 苛

文

齐文

$=\quad$

อี $\frac{\pi}{3}$ 牲

䨌

의 $\quad$

듐

훙ㅎㅇㅇ.

ᄋ 80.

$8 \pi \infty v$

N 2

हैं

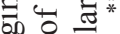

艺昰

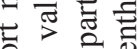

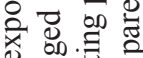

० $00 . \Xi$

:

ख

忢范

क्षे है

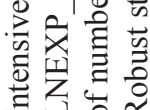

0
$\frac{0}{3}$
$\frac{0}{3}$
0
0
0
0
0 
Katja Zajc Kejžar, Črt Kostevc, Vinko Zaninović • The role of regional economic... Zb. rad. Ekon. fak. Rij. • $2016 \cdot$ vol. $34 \cdot$ no. $1 \cdot 11-41$

ह

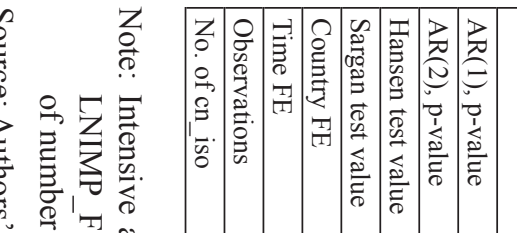

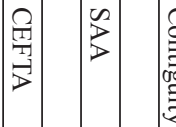

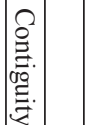

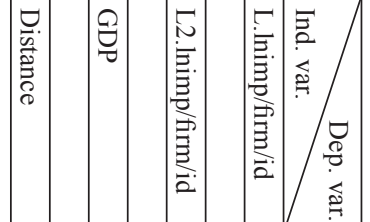

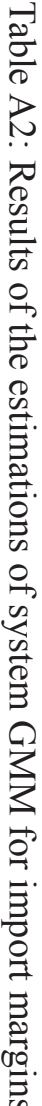

尺ำ 号

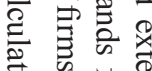

苛 क

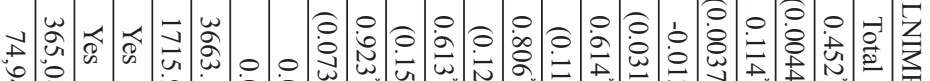

+잉

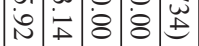

○

声罚

D

言. 范

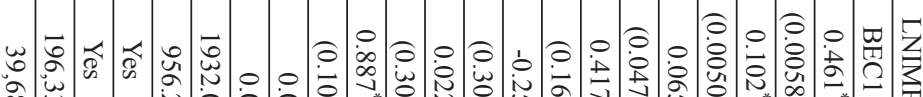

文

in

응

श्ञ

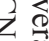

$\infty$ กิด

궁 8

華炁

$\nabla$ क

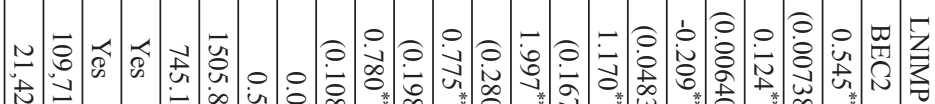

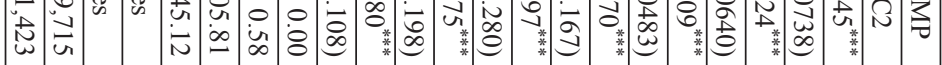

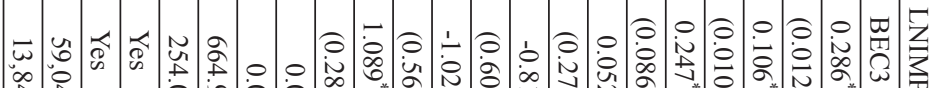

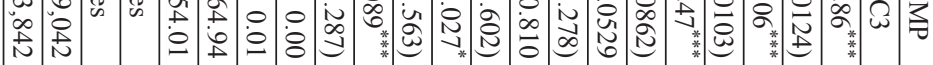

○

旸

党.

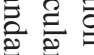

尺

它它

四. 苍

ᄅ

官

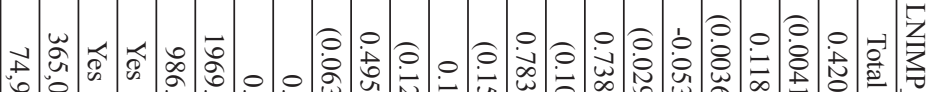

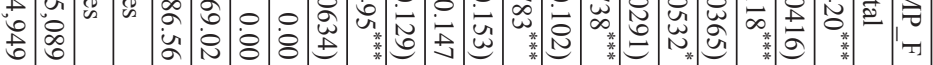

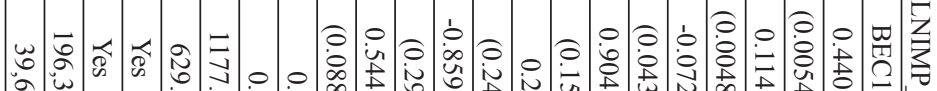

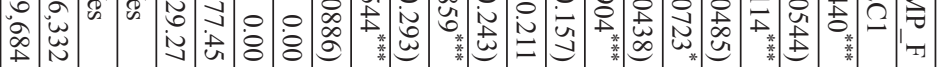

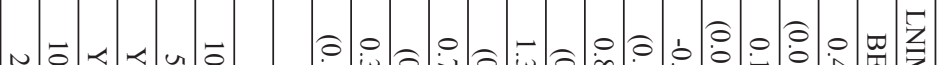

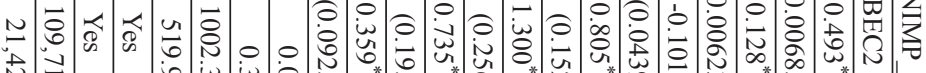

尽。

*.

* ฉ 尺

$\checkmark \stackrel{\sigma}{0}$

○这.

을.

- 응

曲寻寻

○光意

它实。

○

○े है

की

궁

迢出

w)

岂

ลㅇ.

$\circ$

w

品

N

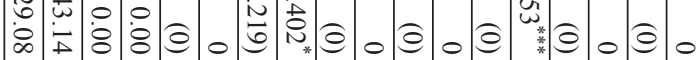

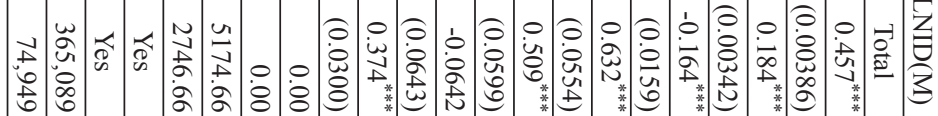

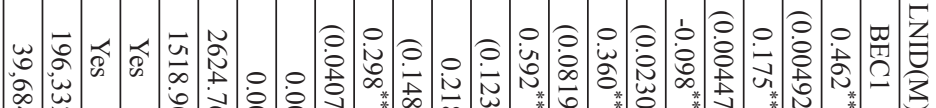
官

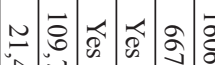

- 0 - - o 0 o

芯柁

ᄀ.

象,

2

คี้

w $\infty$ \& \& 8 * 
Katja Zajc Kejžar, Črt Kostevc, Vinko Zaninović • The role of regional economic...

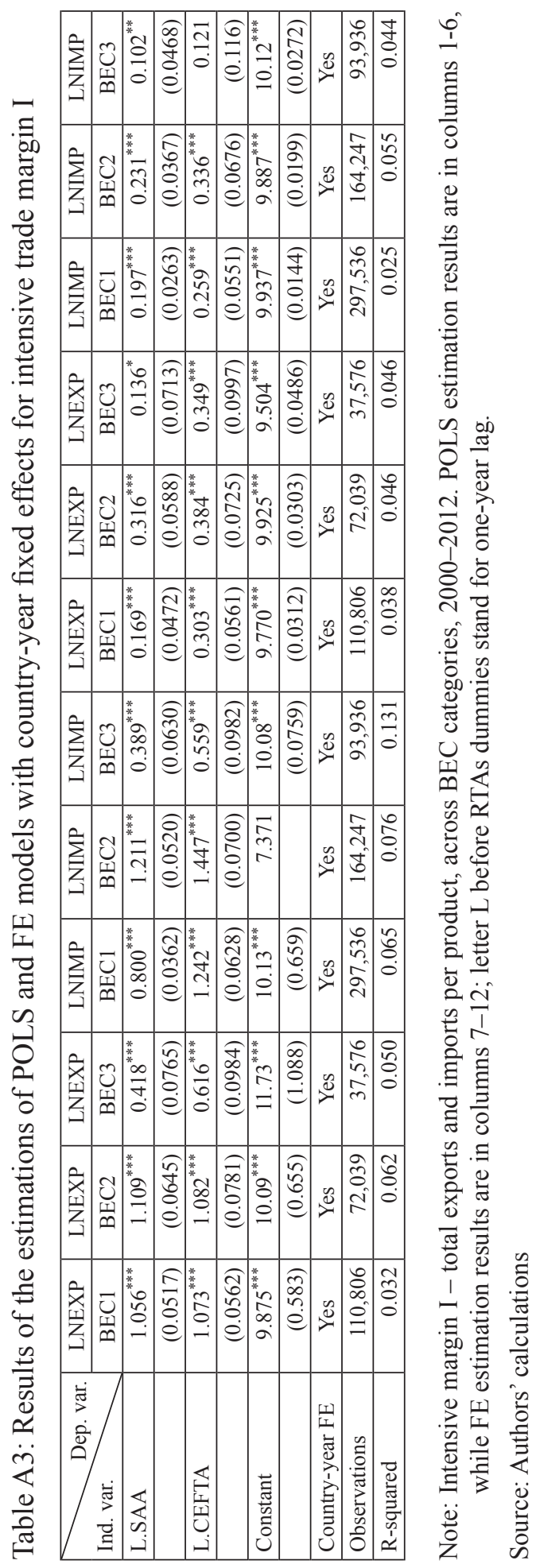


Katja Zajc Kejžar, Črt Kostevc, Vinko Zaninović • The role of regional economic... Zb. rad. Ekon. fak. Rij. $\cdot 2016 \cdot$ vol. $34 \cdot$ no. $1 \cdot 11-41$

号

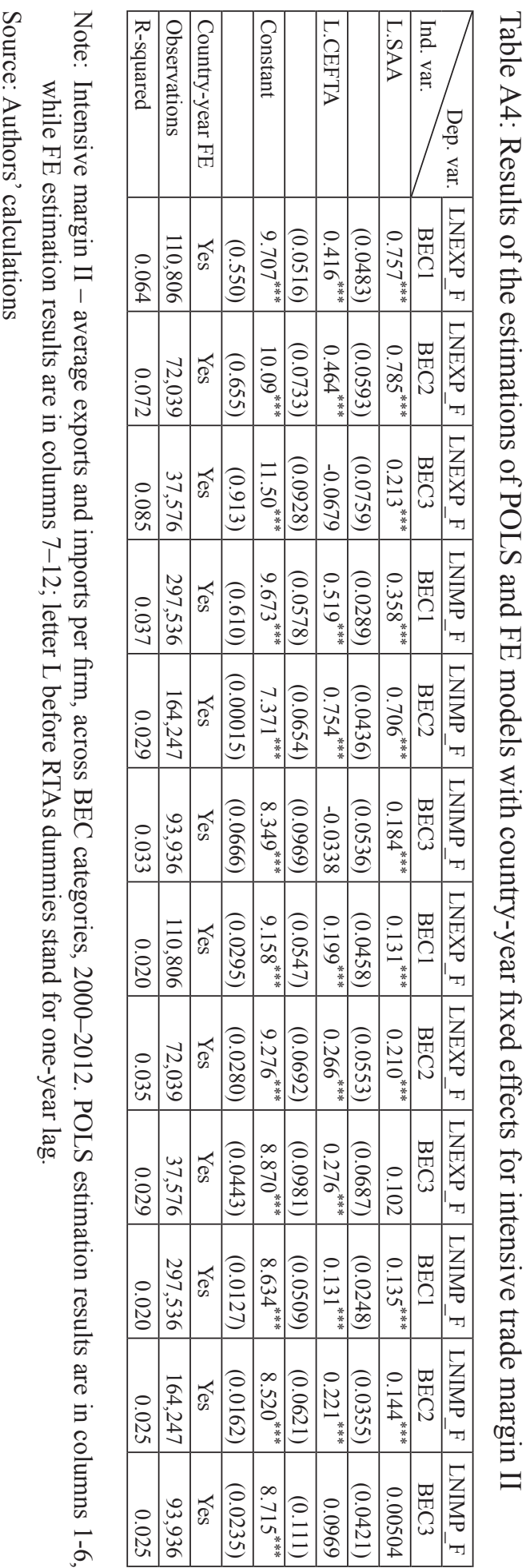


Katja Zajc Kejžar, Črt Kostevc, Vinko Zaninović • The role of regional economic...

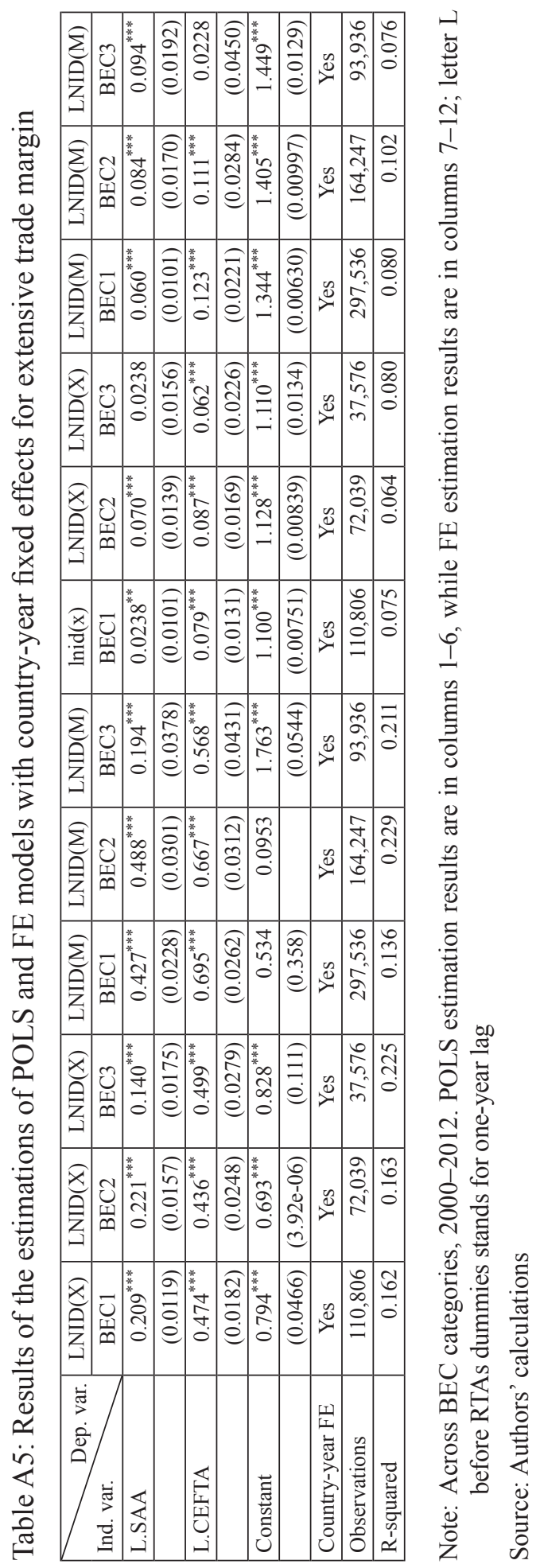

